\title{
THE FACTS ABOUT UNWRITTEN CONSTITUTIONALISM: A RESPONSE TO PROFESSOR RUBENFELD
}

\begin{abstract}
ADRIAN VERMEULE $\dagger$
Professor Jed Rubenfeld's essay “The New Unwritten Constitution" makes some sensible interpretive and normative points. But it seems to assume an empirical picture that is overdramatized. The right starting point is a positive rather than normative account of unwritten constitutionalism. What is it? How broad or narrow is its domain? How has it changed over time? The best positive account suggests that, on a continuum between wholly literalist constitutional interpretation and wholly nontextual or extratextual interpretation, the Court spends most of its time oscillating within a rather narrow band closer to the middle of the continuum than toward either extreme. The interactions among the Court, the other institutions of the national government, and the populace ensure that any systematic push toward one end of the spectrum or the other will prove selflimiting. So the problem of unwritten constitutionalism is normatively important, but it is not nearly as empirically important as Professor Rubenfeld appears to believe.

A preliminary point is that scholars should steer away from sensational charges that this or that decision is either a lamentable exercise in "unwritten constitutionalism" or a laudable but hypocritical one. The first charge commonly is made by textualist critics of nontextualist decisions written by nontextualist Justices, the second by nontextualist critics of nontextualist decisions written by textualist Justices. But there is nothing unique to constitutional law in this debate. In federal jurisdiction the same debate appears in the guise of

Copyright (C) 2001 by Adrian Vermeule.

$\dagger$ Professor of Law, University of Chicago Law School. This Essay is a response to Jed Rubenfeld, The New Unwritten Constitution, 51 DUKE L.J. 289 (2001), presented at the Constitution in Exile conference hosted by the Program in Public Law at Duke University School of Law on October 5-7, 2000. Thanks to Jack Goldsmith for helpful comments.

1. Jed Rubenfeld, The New Unwritten Constitution, 51 DUKE L.J. 289 (2001).
\end{abstract}


the question whether particular decisions count as "interpretation" of federal enactments or as "federal common law." In statutory interpretation the labels are "interpretation" and "lawmaking."

In all of these cases the source of the disagreement is the continuum between literalism and wholly nontextual interpretation. To use Rubenfeld's example of the Eleventh Amendment, at the literalist pole we can imagine how the Court might have decided Hans v. Louisiana $^{3}$ differently: it might have ruled that the Amendment bars only suits between a state and a citizen of another state. An incremental move away from text produces Hans as it actually was decided. The opinion rested on an interpretive canon that even textualists employ: the "absurd results" canon, which the Court invoked in Hans to suggest that it would be terminally absurd to afford states immunity only as to federal court suits by noncitizens. ${ }^{4}$ A further incremental move might have produced an even more fluid, countertextual opinion that would have relied solely upon extrapolation of the purposes of the Amendment's drafters. Finally, Alden v. Maine, which extended state immunity beyond the federal court setting altogether, ${ }^{6}$ exemplified another step toward unwrittenness, as the text-based structural inferences of some of the other federalism cases shaded into looser structural reasoning à la Charles Black. ${ }^{7}$ We can stop at any point along this continuum and brand the next decision along the path as an exercise in "unwritten constitutionalism."

What do we gain from doing so? There is both a normative and a positive question here. The normative question is at what point on the continuum ought we to say that an incremental move has pushed the Court from written to unwritten constitutionalism, from interpretation to lawmaking. Rubenfeld focuses on the normative question but

2. See Richard H. FAllon et Al., Hart \& Wechsler's The Federal Courts AND THE FEDERAL SYSTEM 755 (4th ed. 1996) ("As specific evidence of legislative purpose with respect to the issue at hand attenuates, interpretation shades into judicial lawmaking on a spectrum.").

3. 134 U.S. 1, 15-16 (1890) (holding that the Eleventh Amendment bars federal question suits against a state by a citizen of that state).

4. See id. at 10 (rejecting such an "anomalous result").

5. 527 U.S. 706 (1999).

6. Id. at $738-40$.

7. See generally CHARLES BLACK, STRUCTURE AND RELATIONSHIP IN CONSTITUTIONAL LAW (1965) (discussing various interpretive methods available for textual analysis of statutes); Ernest A. Young, Alden v. Maine and the Jurisprudence of Structure, 41 WM. \& MARY L. REV. 1601, 1604 (2000) (describing Alden as an instance of "the jurisprudence of big ideas"; that is, political theory with an originalist cast). 
never really says what he thinks the terms interpretation and lawmaking mean. But maybe that is a good thing. The normative question is theory-dependent: where we draw the line depends upon what our purposes in drawing it are. So the normative question just plunges us back into the same old debates about interpretive theory-debates about which I have views, and Rubenfeld has views, but that are most profitably conducted in a vocabulary that does not include "unwritten constitutionalism."

The positive question is more fertile. Rubenfeld hints, but only hints, at dramatic recent developments that may even amount to a trend: he says that some recent decisions show that the Court is using a new kind of "unwritten constitutionalism." But we need to beware the Court-watcher's tendency to overestimate the importance of the most recent cases, to generalize from a few data points, and to extrapolate trends to the limits of their internal logic even though trends are usually self-limiting. Against this tendency I want to emphasize two points: historically the Court spends most of its time oscillating within a fairly narrow band in the middle of the continuum; and there are institutional mechanisms that explain why it does and will continue to do so.

It is hardly original to note that there are implicit political constraints that bind the Court within a certain range of departure from the written text. A thoroughly literalist approach to constitutional law would destabilize too much of the New Deal consensus; ${ }^{9}$ that is why really principled textualists, although theoretically cogent, are doomed to political irrelevance. It is more difficult to see the constraint on movement toward a wholly unwritten constitutional law, but it is equally real. The constraint is not the circular idea that other institutions or even voters have a taste for textualist constitutional law, for good reasons or ill, and therefore would punish an excessively free-form Court-or, to put it in the legal process lingo, the vacuous idea that the Court risks a damaging loss of legitimacy when it too obviously departs from its textual moorings. The real textualist constraint is just that adherence to text has effects that the Court finds useful, faute de mieux. Text serves as a focal point for the resolution of pure coordination problems, and it allows the Court to point to

8. Rubenfeld, supra note 1, at 291.

9. Cf. Antonin Scalia, Originalism: The Lesser Evil, 57 U. CIN. L. REV. 849, 862 (1989) (arguing that "faint-hearted originalists" will not want to destabilize too much settled precedent and that most originalists are faint-hearted). 
something other than judge-made precedent or contentious political theory to justify its decisions. The first effect is a constraint, rather than simply a benefit, because the Court usually will gain little by disrupting a settled consensus around a coordinating text even if it later comes to believe that coordinating on some other rule would have been superior ex ante. The second effect is a constraint in the sense that if the Court points to the text when and only when it supports the Justices' attitudes, the Court's audience will correctly perceive that the text lacks any causal force in the Justices' decisionmaking. So the Justices must sometimes invest in credibility by doing what the text says, rather than what they want to do.

Saying that there are constraints on excessive movement toward either extreme of the continuum does not require that the Court's habitual range of oscillation be smack in the middle; that is a different question, a question about how the constraints net out. Over the very long term, the range may drift toward the unwritten end of the continuum; the interpretive life cycle of any written constitution, at least one as difficult to amend as ours, might display decreasing textualism, as precedents accumulate and social problems change. But in any slice of time that lawyers are likely to care about - a generation, saythis process is probably too slow to be important. Certainly we cannot infer from the Printz opinion, ${ }^{10}$ the Boy Scouts opinion, ${ }^{11}$ and the Adarand opinion ${ }^{12}$ that the Court has become increasingly nontextualist. Rubenfeld knows this, because he points toward other recent decisions that appear to take text very seriously, ${ }^{13}$ in tension with his initial claim that the Court is using a "new kind of unwritten constitutionalism."

So the overall picture is that unwritten constitutionalism, like progressive taxation, is both politically inevitable and self-limiting. The normative concerns would be important if the range within which the Court oscillates were greater than it is; but it isn't, so they aren't.

10. Printz v. United States, 521 U.S. 898, 899 (1997) (holding that federal legislation may not constitutionally commandeer states to administer a federal regulatory program).

11. Boy Scouts of Am. v. Dale, 530 U.S. 640, 656 (2000) (holding that a state law requiring the Boy Scouts to admit homosexual scout masters violated the right of expressive association).

12. Adarand Constructors, Inc. v. Pena, 515 U.S. 200, 201 (1995) (stating that all governmental racial classifications are subject to strict judicial scrutiny).

13. See Rubenfeld, supra note 1, at 292 (citing Lopez v. United States, U.S. (reviving Commerce Clause review by appealing to textual "first principles")). 